\begin{tabular}{|c|c|c|}
\hline Case Reports in & \multicolumn{2}{|c|}{ Case Rep Gastroenterol 2018;12:629-632 } \\
\hline Gastroenterology & $\begin{array}{l}\text { DOI: } 10.1159 / 000493421 \\
\text { Published online: October 23, } 2018\end{array}$ & $\begin{array}{l}\text { (c) } 2018 \text { The Author(s) } \\
\text { Published by S. Karger AG, Basel } \\
\text { www.karger.com/crg }\end{array}$ \\
\hline & $\begin{array}{l}\text { This article is licensed under the } \\
\text { International License (CC BY-NC) } \\
\text { Usage and distribution for commerc }\end{array}$ & $\begin{array}{l}\text { nons Attribution-NonCommercial } 4.0 \\
\text { ger.com/Services/OpenAccessLicense). } \\
\text { uires written permission. }\end{array}$ \\
\hline
\end{tabular}

\title{
Successful Treatment of Hepatitis C Virus by Ledipasvir/Sofosbuvir in a Cirrhotic Patient with Sickle Cell Disease and Thalassemia Minor
}

\author{
Hassan Al Moussawi ${ }^{b}$ Abhishek D. Polavarapu ${ }^{a}$ Divya Asti ${ }^{b}$ \\ Zainab Awada ${ }^{\mathrm{b}}$ Stephen Mulrooney ${ }^{\mathrm{a}}$ \\ aDepartment of Gastroenterology, Staten Island University Hospital, Staten \\ Island, NY, USA; 'bepartment of Internal Medicine, Staten Island University Hospital, \\ Staten Island, NY, USA
}

\section{Keywords}

Hepatitis C virus · Ledipasvir/sofosbuvir · Sickle cell disease

\begin{abstract}
Around $8 \%$ of patients diagnosed with sickle cell disease (SCD) are hepatitis $C$ virus (HCV) carriers. Previously, HCV treatment was seldom considered in SCD patients, as the ribavirininduced hemolysis and interferon-induced cytopenias could lead to more profound anemia. Nowadays, several oral direct-acting antiviral drugs have been developed and approved by the FDA for hepatitis $C$ treatment. While direct-acting antivirals mitigate many of these risks, their safety and efficacy in SCD patients remains insufficiently explored. Here, we report on successfully treating HCV with ledipasvir/sofosbuvir in a compensated cirrhotic patient with SCD and thalassemia minor.

(C) 2018 The Author(s) Published by S. Karger AG, Basel
\end{abstract}

\section{Introduction}

In the United States, chronic hepatitis $\mathrm{C}$ virus (HCV) is the most common cause of chronic liver disease resulting in significant morbidity and mortality [1]. Empirical evidence points to 


\section{Case Reports in Gastroenterology}

Case Rep Gastroenterol 2018;12:629-632 DOI: $10.1159 / 000493421$

(c) 2018 The Author(s). Published by S. Karger AG, Basel www.karger.com/crg

Al Moussawi et al.: Successful Treatment of Hepatitis C Virus by Ledipasvir/Sofosbuvir in a Cirrhotic Patient with Sickle Cell Disease and Thalassemia Minor

the presence of correlation among hemoglobinopathies, inheritable blood disorders requiring transfusion, and blood-transmitted diseases. Around $8 \%$ of patients diagnosed with sickle cell disease (SCD) are HCV carriers and are thus at risk of cirrhosis due to both HCV and transfusion-related iron overload [2]. HCV treatment is seldom considered in SCD patients, as the ribavirin-induced hemolysis and interferon-induced cytopenias could exacerbate already pronounced anemia [3, 4]. Although direct-acting antivirals (DAA) mitigate many of these risks, their safety and efficacy in SCD patients remains insufficiently explored. Here, we report on treating HCV with orally administered ledipasvir/sofosbuvir in a compensated cirrhotic patient with SCD and thalassemia minor.

\section{Case Report}

A 32-year-old female that has been a HCV carrier for the past 10 years came to our clinic for hepatitis $C$ treatment. She had not received any treatment for hepatitis $C$ in the past. She also had a history of thalassemia minor and SCD, requiring frequent hospitalizations for sickle cell crisis and multiple blood transfusions. She had undergone splenectomy in childhood and denied illicit drug use, smoking, or alcohol abuse. At the time of her visit, she was taking folic acid only. Her baseline blood workup showed hemoglobin $8.4 \mathrm{~g} / \mathrm{dL}$, platelets $297 \mathrm{~K} / \mu \mathrm{L}$, creatinine $0.33 \mathrm{mg} / \mathrm{dL}$, albumin $3.9 \mathrm{~g} / \mathrm{dL}$, INR 1.1, AST $94 \mathrm{IU} / \mathrm{l}$, ALT $35 \mathrm{IU} / \mathrm{l}$, ALP $96 \mathrm{IU} / \mathrm{l}$, and total bilirubin $2.6 \mathrm{mg} / \mathrm{dL}$. Hepatitis $\mathrm{C}$ viral load was 38,907 IU/mL with genotype 1a. Recent abdominal CT revealed a mildly nodular hepatic contour with hypertrophied left hepatic lobe, indicative of cirrhosis, with no evidence of ascites. The FibroTest revealed severe fibrosis with a score of F4. Hepatitis B surface antigen and HIV antibodies were checked, and both were negative. As the patient had not been previously treated for hepatitis $C$ and had Child-Pugh class A liver cirrhosis with no serologic evidence of HBV and HIV coinfection, once-daily ledipasvir $90 \mathrm{mg} /$ sofosbuvir $400 \mathrm{mg}$ was initiated for 12 weeks. At the 4-week follow-up, the patient complained of mild headache and fatigue. Repeat blood workup showed hemoglobin 7.8 $\mathrm{g} / \mathrm{dL}$, AST $93 \mathrm{IU} / \mathrm{l}$, ALT $49 \mathrm{IU} / \mathrm{l}$, and total bilirubin $2.9 \mathrm{mg} / \mathrm{dL}$, with an undetectable HCV load. Her treatment continued for the remaining 8 weeks, during which headache and fatigue resolved completely. At the end of the 12-week ledipasvir/sofosbuvir course, hemoglobin stabilized at $8.4 \mathrm{~g} / \mathrm{dL}$, and no increase in LDH, total bilirubin or retic count was noted. HCV viral load remained undetectable 3 months after treatment completion.

\section{Discussion}

Liver disease in SCD patients can be caused by many factors, including chronic hepatitis $\mathrm{B}$ or $\mathrm{C}$ infection and iron overload due to multiple blood transfusions or the primary disease [5]. However, although HCV is a significant factor causing cirrhosis in SCD patients, they have traditionally not been offered treatment. This is due to the ribavirin-induced hemolysis that could exacerbate already pronounced anemia and pegylated interferon-related side effects, including but not limited to cytopenia, depression, and influenza-like symptoms [3, 4]. These concerns are justified, given that serious side effects are observed in almost $80 \%$ of patients receiving peginterferon and ribavirin combination therapy for HCV infection [6]. Moreover, as treatment is effective in only about $50 \%$ of patients [6], there is a need for safer and more efficacious alternatives that clears HCV reducing the risk of cirrhosis and other liver-related complications in SCD patients. 
Nowadays several oral DAA drugs have been developed and approved by the FDA for hepatitis $C$ treatment [7]. Available evidence indicates that, as they have fewer side effects, they are well tolerated and have very high cure rates with sustained virologic response in over $90 \%$ of HCV-infected patients [7]. Owing to this advancement in management of hepatitis C, HCV patients are experiencing improved quality of life and have greater life expectancy. Thus, all patients with hepatitis $\mathrm{C}$ should be considered for treatment.

DAA drugs can mitigate many of the risks associated with ribavirin and peginterferon treatment, such as worsening anemia in SCD patients. However, their safety and efficacy in these patients remains insufficiently explored. In one of the few studies in this field, conducted at the Johns Hopkins University [8], the efficacy and safety of ledipasvir/sofosbuvir combination treatment was assessed on a sample of 10 SCD patients diagnosed with hepatitis $C$. The treatment lasted for 12-24 weeks, depending on whether the patient had cirrhosis $(n=9)$ or not $(n=1)$. Subsequent analyses revealed no decline in hemoglobin levels, while 2 patients developed SCD. As the sustained virologic response was $90 \%$, the authors concluded that ledipasvir/sofosbuvir treatment resulted in similar outcomes, irrespective of whether patients had SCD [8].

Our patient had treatment-naïve HCV genotype 1a and compensated liver cirrhosis with METAVIR stage F4. As per the American Association for the Study of Liver Diseases/Infectious Diseases Society of America (AASLD/IDSA) practice guidelines, she can be treated with oncedaily ledipasvir $90 \mathrm{mg} /$ sofosbuvir $400 \mathrm{mg}$ for 12 weeks [9]. To our knowledge, no prior reports on a successful 12-week treatment of HCV with ledipasvir/sofosbuvir in a compensated cirrhotic SCD patient exist in the pertinent literature. Our findings are also novel in that, along with SCD, our patient also has thalassemia minor, thereby elevating the risk of worsening anemia. Nonetheless, the combination treatment resulted in a sustained virologic response, and the only side effects reported by the patient were mild headache and fatigue, which are common for DAA drugs, and were resolved by the treatment completion. Most importantly, no sickle cell crisis, worsening of anemia or decompensation of liver cirrhosis occurred during treatment or in the subsequent 3-month follow-up period.

Thus, we conclude that cirrhotic patients with hepatitis C and SCD can be safely and effectively treated with 12 weeks of once daily lepidasvir $90 \mathrm{mg} / \mathrm{sofosbuvir} 400 \mathrm{mg}$. That being said, further studies are required to fully establish the safety and efficacy of this drug combination and other DAA drugs in treating SCD and other hemoglobinopathies.

\section{Statement of Ethics}

Approval from the ethics committee was not required for this case report. Written informed consent was obtained from the patient for publication of this case report and any accompanying images.

\section{Disclosure Statement}

None of the authors has any financial conflicts of interest to declare. 
Al Moussawi et al: Successful Treatment of Hepatitis C Virus by Ledipasvir/Sofosbuvir in a Cirrhotic Patient with Sickle Cell Disease and Thalassemia Minor

\section{Author Contributions}

H. Al Moussawi, A.D. Polavarapu, Z. Awada, and D. Asti wrote and edited the article. Dr. S. Mulrooney critically revised the manuscript. A.D. Polavarapu is the corresponding author.

\section{References}

1 Chen SL, Morgan TR. The natural history of hepatitis C virus (HCV) infection. Int J Med Sci. 2006;3(2):47-52.

2 Gardner K, Suddle A, Kane P, O'Grady J, Heaton N, Bomford A, et al. How we treat sickle hepatopathy and liver transplantation in adults. Blood. 2014 Apr;123(15):2302-7.

3 Lauer GM, Walker BD. Hepatitis C virus infection. N Engl J Med. 2001 Jul;345(1):41-52.

4 Fried MW, Shiffman ML, Reddy KR, Smith C, Marinos G, Gonçales FL Jr, et al. Peginterferon alfa-2a plus ribavirin for chronic hepatitis C virus infection. N Engl J Med. 2002 Sep;347(13):975-82.

5 Gürkan E, Ergun Y, Zorludemir S, Başlamişli F, Koçak R. Liver involvement in sickle cell disease. Turk J Gastroenterol. 2005 Dec;16(4):194-8.

6 Feld JJ, Hoofnagle JH. Mechanism of action of interferon and ribavirin in treatment of hepatitis C. Nature. 2005 Aug;436(7053):967-72.

7 Falade-Nwulia O, Suarez-Cuervo C, Nelson DR, Fried MW, Segal JB, Sulkowski MS. Oral direct-acting agent therapy for hepatitis C virus infection: a systematic review. Ann Intern Med. 2017 May;166(9):637-48.

8 Terrault NA, Zeuzem S, Di Bisceglie AM, et al. Effectiveness of ledipasvir-sofosbuvir combination in patients with hepatitis $C$ virus infection and factors associated with sustained virologic response. Gastroenterology. 2016;151(6):1131-1140.e5.

9 The American Association for the Study of Liver Diseases and the Infectious Diseases Society of America. Recommendations for testing, managing, and treating hepatitis C [cited 2015 Aug 27]. Available from: http://www.hcvguidelines.org. 